\title{
Idrætsforskning som kulturforskning i et globaliseringsperspektiv ${ }^{1}$ \\ af Jørn Møller
}

\section{Introduktion}

Antropologien har sine klassiske paradokser:

Skal antropologen gøre sin indflydelse gældende, når hun bliver vidne til ritualer, som efter hendes begreber er barbariske, eller skal hun forsøge at agere neutral iagttager? Hvad hvis ritualerne er iscenesat til ære for hende selv? Hvad hvis de krænker menneskerettighederne? Hvad hvis det er hendes egne landsmænd, som udsættes for dem?

Bør antropologen rapportere om de dybt tabuiserede hemmeligheder, som stammens shaman betror hende på den udtrykkelige betingelse, at hun aldrig må røbe dem? Er et løfte et løfte, eller er et løfte kun gyldigt i ens egen kulturelle sammenhæng? Skulle hun snarere helt afstå fra at få del i den hemmelige viden?

Hvis det løfte, hun giver shamanen, ikke gælder i enhver sammenhæng, kan man i hvert fald næppe heller gøre krav på, at menneskerettigheder skulle have universel gyldighed, og så må hun afstå fra moralske korrektioner af stammens rituelle adfærd. Omvendt ...

Lignende dilemmaer opstår, når den indfødte kulturforsker optræder internationalt. Danske elevatorer er ofte forsynet med et lille lysskilt, som fortæller, når elevatoren er »I Fart «. På engelsk betyder det »jeg prutter« eller »jeg kludrer i det«, og det kan symbolisere problemer, som ikke alene vedrører danskeres internationale sportspræstationer, men også de vanskeligheder, som kommer bag på dansk idrætsforskning i international sammenhæng.

Jeg vil i det følgende begrænse disse vanskeligheder til blot tre områder:

Relevans, sprog og forholdet mellem uddannelse og forskning.

\section{Relevans}

Dengang mange af Europas nationalstater blev dannet, i slutningen af det 18 . og begyndelsen af det 19. århundrede, havde de centrale dele af Danmark allerede været en etnisk, geografisk, religiøs og konstitutionel enhed i mindst 800 år. Ganske vist havde landet lejlighedsvis været involveret $\mathrm{i}$ imperialistiske og multinationale eventyr, men takket være mislykkede krige, dårlig økonomi og uheldige alliancer blev de fleste udenlandske besiddelser og forpligtelser afviklet i løbet af 1800-tallet. Det som nu er tilbage, Færøerne og Grønland, går formodentlig en temmelig usikker fremtid i møde som del af det fælles kongerige. ${ }^{2}$

Tabet af det lille imperium gav næring til en ny og romantisk æra, som indledtes med admiral Nelsons ødelæggelse af den danske flåde, fortsatte med kongens ønske om at måtte dø i sin rede under bombardementet i 1807, videre over statsbankerotten, tabet af Norge, slaget ved Isted med 
foreløbig kulmination i besættelsestiden med eftertidens myte om det lille enige folk, som stod sammen i svære tider.

Det var fædrelandskærlighedens ånd, eller snarere en blød, venlig, syngende, flaghejsende og ikke særlig militant nationalisme, som understregede naturens skønhed, den flittige borger, pigernes troskab, modersmålet, folket, og med tiden også de demokratiske dyder, der har givet sig udtryk i en usædvanlig stærk identifikation mellem befolkningen og staten, som i ramme alvor anses for at udspringe af det civile samfund, folkeviljen.

Selv i dag er der vel få udsnit af befolkningen, som synes, de har mere til fælles med beslægtede udenlandske grupper, end de har med andre grupper af danskere. ${ }^{3}$ En fælles historie, sproglig og religiøs ensartethed i rammerne af en stabil nationalstat, som omfatter blot 5 millioner indbyggere har skabt en dansk stammefølelse, som ud fra mange synsvinkler er irrationel, men som på den anden side er en slags identitetsklister, der giver svar på spørgsmålene om, hvem man er, og hvad man er.

Idrætten har i tidens $1 \varnothing b$ ydet sit bidrag til denne nationale konsolideringsproces: Den tyske »Turnen «, svensk gymnastik og engelsk sport blev indført, og gennem skoleidrætten og dannelsen af frivillige sportsklubber og skytte-, gymnastik- og idrætsforeninger kom de forskellige retninger til at føles hjemlige, og de bidrog hver på deres måde til at understøtte særlige følelser af danskhed. ${ }^{4}$

Idrætten og idrætsuddannelserne i Danmark er stærkt præget af denne tradition og kan ikke forstås uden særligt kendskab til deres historiske tilblivelse. Ud fra et effektivitetssynspunkt er en sådan fortid meningsløs, og organisationsteoretikere ville kunne pege på, at idrætten ville stå bedre i henseende til økonomi, effektivitet, opfyl- delse af uddannelsesmæssige og politiske mål o.s.v., hvis man ikke tog hensyn til en fortid fyldt med dårlige vaner, obskure ritualer, uhensigtsmæssige traditioner og hysteriske følelser. I en diskussion af historiens værdi er det imidlertid en pointe, at dansk idrætsliv ikke fungerer dårligt på grund at den historiske last, det slæber med sig, men snarere at det får sin særlige karakter og mening på grund af traditionen.

Det kan være, at idræt i sig selv ikke først og fremmest er et spørgsmål om rationel funktion og effektivitet, skønt det godt kunne se sådan ud, i den udstrækning man lægger vægt på uddannelsesmæssige mål og falder på halen for såvel gode personlige som nationale resultater, baseret på rationelt tilrettelagt præstationsfremgang. Utålmodighed vedrørende resultater og ønsket om at finde eksakte mål for effektiviteten svarer imidlertid til at trække radiserne op for at se, om de gror. Væksten i sig selv kan karakteriseres ved kropserfaring, kropslig udtryksfuldhed, livsudfoldelse, følelser, lyst og mangel på alvor og fornuft, noget som ikke tjener vigtige formål, men i snæver forstand er unyttigt tidsfordriv. Altså: idræt er kultur, eller med Buytendijk (1933): Fuglene synger mere end Darwin anser for passende. ${ }^{5}$

Idrætsudfoldelse er ikke blot bevægelseslære og resultater, det er også mening og indhold, ligesom oplevelsen af en smuk solnedgang. Men hvem har hørt en idrætslærer påstå, at det vigtigste ved idræt er den unyttige fornøjelse - der ikke er godt for noget - som man kan have af at kaste sig ud i den? Det er der ingen penge eller jobs i. Og for resten: Hvordan evaluerer idrætslæreren følelsen af livskraft og oplevelsen af livskvalitet, når hans vigtigste redskab er målinger af puls og personlige rekorder?

I denne sammenhæng kan idrættens stade i et givet samfund kun forstås i ureflek- 


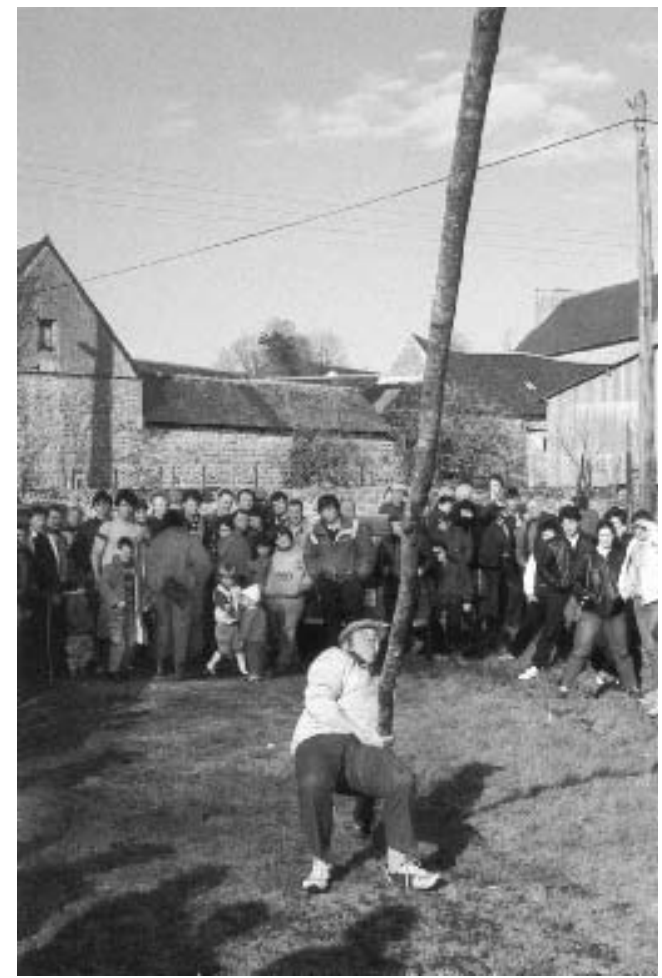

Idratsforskning er kulturforskning: »Lever la perche«, Bretagne.

teret medleven, som kropslig erfaring og tilstedeværelse, hvor den foregår, eller måske, mere videnskabeligt, i velovervejet og detaljeret kendskab til de særlige, historiske og kulturelle omstændigheder. Erkendelsesredskaberne kan være historiske, antropologiske, æstetiske eller semiologiske, mens funktionalistisk forskning burde anvendes hovedsageligt for at minimere de risici og farer, der er en del af fornøjelsen. Ud fra et kulturelt synspunkt er det i det mindste værd at lægge sig på sinde, at naturvidenskaberne end ikke er i besiddelse af definitioner, der gør det muligt at skelne idræt fra arbejde, hvilket faktisk er en af kulturforskningens hovedpointer. For at opsummere Eugen Fink i hans fremragende essay om legens ontologi, så er leg ikke blot en terapi mod centrale forstyrrelser i det moderne menneskes liv. Leg er selve det uforstyrrede centrum i menneskelig virksomhed. ${ }^{6}$

I globaliseringsprocessen ses det imidlertid, hvordan idrætslivet opsluges af international professionalisme og udtrykkes i kommercielle showsportsbegivenheder. En Bermudatrekant af kommercielle organisatorer, sponsorer, og medier er blevet skabt, og det verdensproletariat, som samles foran TV-skærmene, kan fra denne position overvære, hvorledes idrætsglæden og det folkelige idrætsliv forsvinder i præcis samme udstrækning, som der opstår en form for cirkus. I en sådan international sammenhæng er det svært at se relevansen af den historiske detalje i de lokale idrætsformer, som handler om livet i modsætning til resultaterne, og den internationale idrætsforskning risikerer i endnu højere grad end de lokale idrætsforeninger at komme til at fokusere på Bermudatrekanten som fællesnævner.

Kulturforskning er i sig selv kultur. Det betyder at kulturforskningen er en del af et givet samfunds oplysningsniveau. Hvis den lokale kulturforsker bruger sine evner og kræfter på at koncentrere sig om den internationale sportsudvikling og på at informere det internationale samfund herom, så har en sådan bestræbelse andre konsekvenser for den lokale kulturproces end lokal forskning, som publiceres lokalt, og lokalsamfundet kan på den måde let frarøves én dagsorden og ledes ind i en helt anden.

Bøje og Eichberg (1994) påviste, at administrationen af bestemte aspekter af moderne præstationsidræt er i modstrid med kulturværdier, som normalt værdsættes i det danske samfund. ${ }^{7}$ Det er selvfølgelig ikke uden betydning for det internationale samfund, men relevansen er langt højere i lokal sammenhæng, og måden at rapporte- 
re på må nødvendigvis være langt mere detaljeret, end det ville være tilfældet i en international kontekst.

Tilsvarende relevansproblemer opstår, når det drejer sig om at gennemhulle myter: Her i landet er det børnelærdom, og et ufravigeligt politisk dogme, at dannelsen af frivillige idrætsforeninger udgør en vugge for demokratiet. Det er naturligvis en vigtig information at give videre til resten af verden, eftersom den kan have en eller anden form for modelstatus. I sin forskning påviser Ibsen (1992) imidlertid, at myten ikke altid holder. ${ }^{8}$ Det er en indsigt, som er vital i lokal sammenhæng, men internationalt set ligegyldig i det omfang, man er lykkeligt uvidende om den oprindelige myte.

Selv har jeg samlet 400 traditionelle lege fra det danske område, ${ }^{9}$ og det ville have været temmelig uhensigtsmæssigt først at udgive dem på engelsk, eftersom de udgjorde en glemt del af den danske kulturarv. Lokal og global er to forskellige steder, og forskeren kan ikke altid være begge steder på en gang.

\section{Sproget}

Kulturforskning er i sig selv kultur. Dansk har overlevet som sprog i tusind år. Under denne proces er det blevet påvirket af mange andre sprog. Når det skete, blev det oftest betragtet som en trussel, men ved nærmere eftertanke blev det altid set som en berigelse. For tiden er den angelsaksiske indflydelse enorm, hvilket især skyldes de elektroniske kommunikationsmidlers udvikling. Som et lille land, der deltager i den internationale proces, behersker mange mennesker mindst ét og ofte to eller tre fremmedsprog. $\mathrm{Nu}$ har Kulturministeriet imidlertid givet udtryk for en vis bekymring: »I internationaliseringsprocessen bli- ver vi, med de mange kulturelle påvirkninger udefra, beriget med større viden om og forståelse for andre lande og folk. Det danske samfund og dansk identitet har haft stort udbytte af den proces. Men der skabes samtidig et stort behov for at have et kulturelt udgangspunkt, vi kan sætte de mange påvirkninger fra fremmede kulturer i forhold til. Kulturpolitikken skal generelt medvirke til at skabe en stærk bevidsthed om dansk identitet og dens udvikling... $\ll^{10}$ Og videre signalerer redegørelsen en $\emptyset$ get støtte til kunsten og til en lang række kulturelle aktiviteter og ytringer, der anskues som fremmende for dansk sprog. Selvrespekt, der sikres gennem en identitet baseret på eget sprog og egne kulturværdier, er den underliggende filosofi. Således udrustet kan danskerne være åbne over for fremmed indflydelse uden frygt for a miste, hvad der er mere værdifuldt i deres egen kulturelle arv.

Hvad angår idrætsforskning udgør danske idrætsfolk næppe nogen undtagelse, når de ikke er de flittigste læsere af refleksioner vedrørende deres idrætsområde eller praksis, med mindre det er ekstremt funktionelt og brugbart her og nu. Hvis man derfor i debatten om idræt og kultur $\emptyset$ nsker at involvere dem, det vedrører, og det er kulturforskningens pointe, så er det nødvendigt med en appetitlig sproglig tilgang, og den kan man ikke opnå på et fremmedsprog. I den henseende synes det lokalt orienterede Kulturministerium og den internationalt orienterede forskningsadministration at være på kollisionskurs. I redegørelsen for sine strategiske planer siger Forskningsrådet: »Internationaliseringen er vigtigere i dag end nogensinde ... Der ofres betydelige ressourcer på netværk, rejser, konferencer, gæsteprofessorordninger, ph.d.- kurser med internationalt perspektiv, oversættelses- og publikationsstøt- 
te osv... [Men] det gælder såvel for seniorforskere og Ph.D.-ere, at der er for få midler og samtidig også en række strukturelle forhindringer [sic!] for en uproblematisk [sic!] internationalisering. $\ll^{11}-$ Som om internationalisering nogen sinde var uproblematisk, og som om 1000 års danskhed blot var en strukturel hindring! Må vi være fri!

På humaniora kan man stadig præsentere sine forskningsresultater på dansk, men hvis man vil have en karriere, kan det være en alvorlig hindring at gøre det. Denne holdning indebærer, at kulturforskningens bidrag til vedligeholdelsen af det danske sprog begrænses. Det er afrikanske eller orientalske forhold og fra et kulturelt synspunkt næppe særlig progressivt. Dertil kommer, at international forskning henvises til at fremstille komplicerede sager på et fremmedsprog, hvilket afstedkommer tre problemer:

For det første et vaklende, unuanceret sprogbrug, som er netop en kulturforskning uværdig, For det andet et oversættelsesproblem, som er selve kulturens kerne, og som refererer til den kendsgerning, at selv korrekt oversættelse rummer vidt forskellige kulturelle konnotationer. Det bedste eksempel fra idrætsforskningsområdet er oversættelsen af et simpelt ord som 'sport', der har forskellig betydning og forskellige konnotationer på engelsk, tysk, dansk, finsk osv. De skandinaviske lande har to ord for sport: idræt, der kommer fra oldislandsk, og sport, der kommer fra det engelske. Disse begreber dækker en del af det engelske ords semantiske felt, men udelukker visse fænomener der på engelsk er karakteriseret som sport, og de implicerer andre, englænderne ikke ville kalde sport. Også treenigheden leg-spil-sport har forskellig afgrænsning fra kultur til kultur. Tyskerne har således kun ordet »Spiel« som begreb for leg og spil. Meget af det, som i Danmark i dag kaldes gymnastik ville en amerikaner sandsynligvis identificere som $\gg$ dance $\ll$.

Det tredje problem vedrører den intellektuelle »forurening « af det fremmedsprog, man betjener sig af. Maliciøst kan man anskue det som en sød hævn i forhold til de problemer, man selv må igennem, men forureningen er allerede gennemgribende, når det drejer sig om tekniske og naturvidenskabelige afhandlinger på fremmedsprog.

\section{Uddannelse og forskning}

Kulturforskning er i sig selv kultur, og kultur er grundlæggende historisk, mangfoldig, lokal og varieret. De enkelte kulturer deler naturligvis visse universelle træk, men både de mest avancerede fornøjelser og de mest komplicerede problemer udspringer af mangfoldigheden, så indtil videre er det - på trods af internettets, kapitalens og naturvidenskabernes rolle i verden - ren ideologi at snakke om en universel kultur. Ikke desto mindre går hovedvejen til en akademisk karriere gennem en international meritation, hvis inspiration er markedskræfterne, og hvis standarder i vidt omfang er en kopi af naturvidenskabernes. »Internationalisering « og »globalisering « er slagord, der refererer til en udvikling, der fremstilles som et uomgængeligt gode, mindre kritisk end når bønderne i gamle dage sagde: »Man må jo følge med udviklingen."

Et led i denne udvikling var dannelsen af det særlige Forskningsministerium, der i 1993 blev udspaltet fra Undervisningsministeriet. Dermed brød man med et gammelt universitetsprincip, nemlig ideen om, at der skulle være en tæt forbindelse mellem forskning og universitetsundervisning, eftersom bevillinger til de to områder nu 
kom fra to forskellige kilder med hver deres kriterier. Fremover skulle forskningsmidler primært tildeles på grundlag af forskningsrådenes strategiske planer, mens undervisningsbudgetterne i hovedsagen blev et kvantitativt anliggende, hvis størrelse især kom til at afhænge af, at institutterne producerede flest mulige kandidater på kortest mulig tid.

Der er næppe tvivl om, at man på den måde kom megen dovenskab til livs. Det er muligvis også en fordel for naturvidenskaberne, fordi de ofte arbejder med globale problemer. Skønt afdækkelsen af naturlovene er et udpræget historisk fænomen, er natur trods alt mere universel end kultur, så ordningen sætter formentlig naturvidenskaberne i stand til at holde trit i den internationale udvikling, og indtage den plads de har råd til, i en verdensomspændende fordeling af opgaver.

Men i humanistisk kulturforskning, idrætsforskningen inkluderet, er spørgsmålet om international sammenlignelighed kun et enkelt aspekt. Ikke desto mindre var der en komite under Humanistisk Forskningsråd, som i 1997 betragtede internationaliseringen sammen med selve finansieringsgrundlaget som en hovedbetingelse for humanvidenskaberne og også fastslog nødvendigheden af at foretage evalueringer i overensstemmelse med internationale standarder. ${ }^{12}$ Det lyder meget uskyldigt, fordi intentionen, som ingen kan indvende noget imod, er at tilvejebringe god og relevant forskning i store mængder. Men når standarderne tages fra naturvidenskaberne, og sproget fra den industrielle produktions management, er der grund til bekymring. Forskning, som passer ind i og fremmes af en sådan kontekst, må fortrinsvis indgå i store strategiske programmer og udmunde i fremmedsprogede rapporter, undersøgelser, og internationale præsentationer. Det vil være en produktion, som især skal tilgodese forskningsrådenes legitimationsog effektivitetsbehov. Fagfolk ved, hvad alibifodbold er, og det er nærliggende i denne forbindelse at tale om alibiundersøgelser. EU afholder sig i nogen udstrækning fra kulturforskning, men initierer undersøgelser med nogen affinitet, der skal udgøre et vidensgrundlag for udformningen af politikker på givne områder (ungdom, uddannelse, fritid, turisme). Generelt er de forskellige data forældede, inden rapporterne når frem, de er i alle tilfælde usammenlignelige, men sammenlignes alligevel, og konklusioner og henstillinger er under alle omstændigheder uigenkendelige, hvis en rapport skulle nå hele vejen igennem den politiske mølle og opnå den tvivlsomme status at være det påståede grundlag for et program. - Og det er godt det samme.

De internationale standarder kan udmærket være egnede i den strategiske forskning og i den kumulation af »universel« viden, som er karakteristisk for naturvidenskaberne. Deres data har trods alt den egenskab, at de ikke ændrer sig uafladeligt, ligesom deres definitioner kan opnå en vis entydighed, og i en vis udstrækning kan hæves over tid og sted, men standardiserede metoder og strategisk forskning er ubrugelig eller dybt ensporet, når det drejer sig om kulturel udvikling blandt danske atleter og deres organisationer.

De er svære at anvende lokalt, da de i reglen fører til uniformeret og standardiseret bogholderi og kortlægning efter kriterier og definitioner, hvor der må hakkes og klippes, før de kan appliceres, og resultatet er, at ny viden baseret på en ægte forståelse af de lokale forhold tilsidesættes.

Når det drejer sig om historisk viden, volder tid og sted særlige problemer, fordi tid og sted uafladeligt påvirker metoder og 


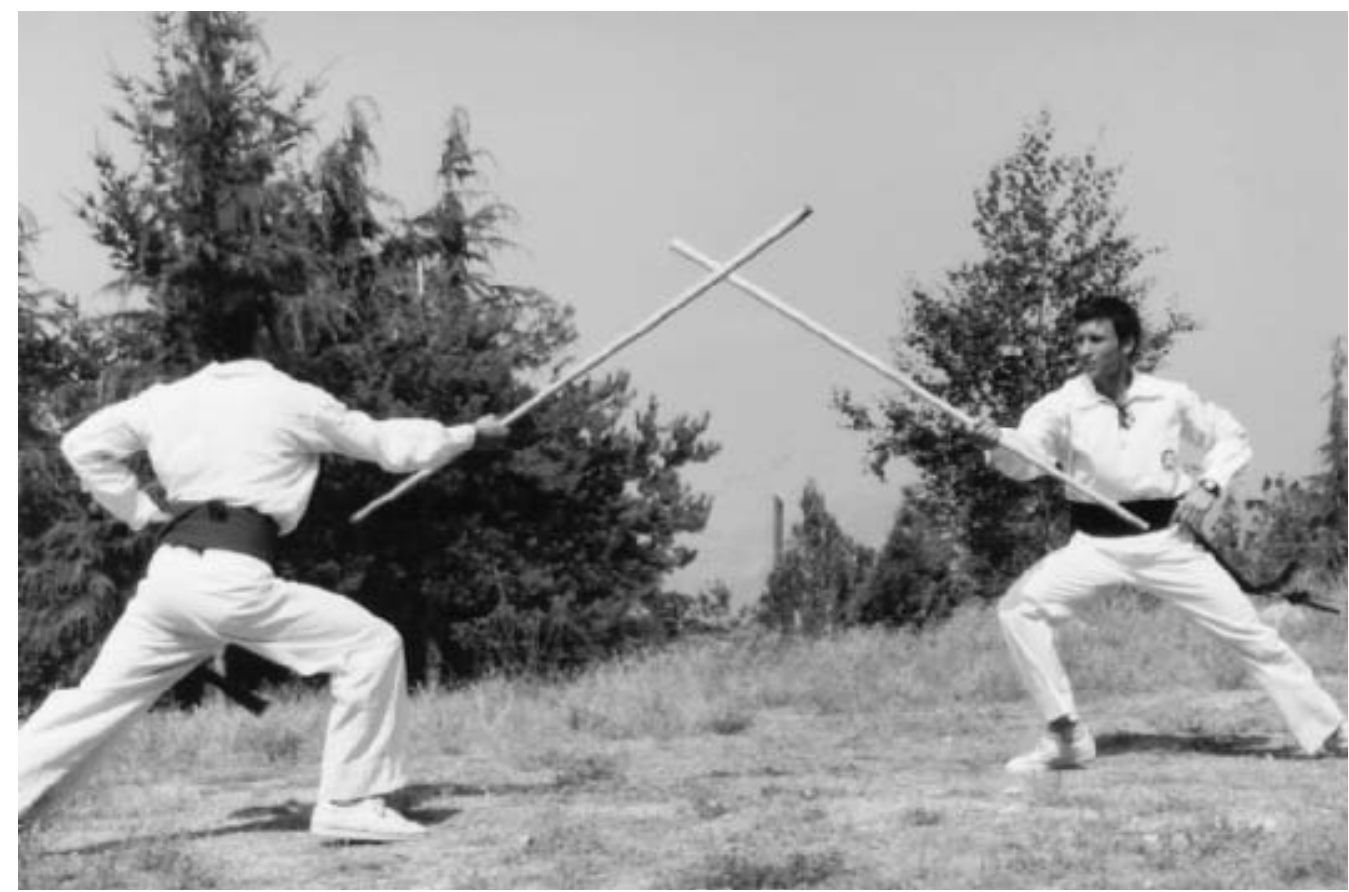

Kulturforskning er lokal: »Jogo do Pau«, Portugal.

definitioner, men også selve den kulturelle erkendelses natur adskiller sig fra naturvidenskabernes teknisk-deskriptive ekspertviden. Ved i sig selv at være kultur (det er naturvidenskabens erfaringer også, men det kan man pr. konvention et langt stykke af vejen se bort fra; hvilket ikke er muligt og ikke er meningen, når det drejer sig om kulturelle erfaringer) er viden om kultur mindre karakteriseret ved dens evne til at ophobe information beregnet for evigheden, end ved dens evne til at indgå i den offentlige diskussion og på den måde bidrage til argumentationens niveau og debattens gennemsigtighed. Den er diskursiv og ikke kumulativ.

Oven i dette kommer hele spørgsmålet om forvaltningen af den danske kulturarvs mere konkrete efterladenskaber. Her er udenlandske forskere, antropologer osv. naturligvis yderst velkomne. De er givetvis de bedste til at få øje på de særpræg og selvfølgeligheder, som i et internationalt perspektiv slet ikke er selvfølgelige. Men selv hvis dansk forskningskvalitet (for nu at bruge et forretningsmæssigt udtryk) skulle være beskeden, må det forekomme tvivlsomt, om forskning i de nationale arkiver og museer i så fald bedre kunne overlades til velmeriterede udenlandske kolleger, hvilket ville være tilfældet, når talen er om naturvidenskabelige emner. Forvaltningen af den danske kulturarv er naturligvis på godt og ondt primært et dansk anliggende. Enhver kan se, at en henlæggelse af samlingerne og forskningen til f.eks. England, EU eller USA ville være en handling, der bevidst sigtede på opløsningen af en særlig dansk identitet. Uanset hvilke rationaliseringsgevinster, man måtte opnå, flytter man heller ikke Det Kgl. Teater til Berlin, og præcis samme overvejelser må gøre 
sig gældende, når det drejer sig om forskerrekruttering. Det var vel også sådanne overvejelser, som gjorde sig gældende, da Danmark stik mod præcedens i alverdens museer udleverede de islandske håndskrifter.

Latin blev som afhandlingssprog afskaffet på Københavns Universitet for cirka 200 år siden, og som fagterminologi har det kun kunnet holde ganske få bastioner. Det blev afskaffet i en tid, hvor enevælden vaklede, og humanvidenskaberne vandt frem som central institution i et omfattende nationalromantisk projekt. ${ }^{13}$ Nordisk mytologi blev omhyggeligt blandet med teologi og klassisk dannelse. Præster, jurister, lærere og andre embedsmænd blev bærere og bevidste formidlere af en særlig dansk (læs i den kontekst: særlig god) teologi, retsfølelse, litteratur, filosofi og samfundsopbygning. Det hele blev dokumenteret og underst $\varnothing$ ttet af historikere, som regelmæssigt genskrev kongernes nationale historie.

Projektet forløb parallelt med lignende nationale projekter i det omliggende Europa, og indholdet var måske ikke så meget anderledes, men det troede man, og derfor fik projektet overordentlig stor betydning for homogeniteten, stabiliteten og sammenhængskraften i det danske samfund. Projektet har været så stor en succes, at det i dag volder problemer at få danskerne med på ideen om EU, men meget tyder på, at det er under afvikling. Hvad der i disse tiår sker på universitetsområdet er formentlig en revolution på det åndelige plan, der kan matche hele dette århundredes materielle udvikling. Et nyt pavedømme er under oprettelse, anonymt styret af den »udviklede « verdens materielle fremskridt, og de intellektuelles kamp om hvem der kan få de bedste pladser og de største goder på det angelsaksiske elitehold.

\section{Konklusion}

Nationalstaten har sine mørke sider. TV såvel som historiebøgerne flyder over med eksempler. Globalisering og verdenshandel har sin klare ideologi med åbenhed og forbrødring som endemål, men kulturel internationalisering er også kulturel nivellering, og det er vanskeligt ikke at opfatte kulturel nivellering som forarmelse. Konklusionen peger ikke på nogen som helst form for isolationisme, men kulturforskeren (idrætsforskeren) må forsøge at være »glokal«, ansvarlig over for både den lokale stamme og det internationale samfund. Om en medierende neologisme som $»$ glokal « har noget som helst indhold, ${ }^{14}$ eller den blot tjener til en tilsløring af problemerne, må tiden vise.

I en sådan proces må det være vigtigt, at lokale forskningsinstitutioner og råd reflekterer deres dobbelte ansvar i meritations- og bevillingkriterierne. Omvendt må internationale komiteer og råd se i øjnene, at kvalitet i humanvidenskaberne adskiller sig fra kvalitet i naturvidenskaberne. Også spørgsmålet om relevans er kildent. Hvad der er relevant i en lokal sammenhæng, kan være uinteressant $i$ en international og omvendt. Internationaliseringen på det humanvidenskabelige område vil helt givet medføre en fuldstændig ligegyldig kongreskultur, der udelukkende tjener som supplement til turistindustrien. Den kan også bidrage til en ganske udemokratisk uddybning af kløften mellem forskning og befolkning, fordi forskerne præsenterer deres resultater i udenlandske »papers « i stedet for at skrive gode danske bøger. Fremfor at gå ud fra, at al internationalisering er af det gode, må det derfor være enhver kulturforskningsadministrations opgave at sikre, at internationale samarbejdsformer frugtbargøres lokalt. 


\section{Noter:}

1. Artiklen er en bearbejdet version af et paper, præsenteret på The NASSH (North American Society for Sport History) Annual Convention, Windsor, Ontario, Canada, May 1998. Manglende sproglig præcision kan skyldes oversættelsen fra denne kontekst og understreger på den måde min pointe.

2. Olav Olsen (ed.) Gyldendal og Politikens: Danmarks Historie, vol. 10, Claus Bjørn: 1800-1850, vol. 11 Kristian Hvidt: 1850-1900. Copenhagen 1990.

3. Feldbæk, Ole (ed.): Dansk Identitetshistorie vol. 3, C.A. Reitzel, København 1992, p. 337 ff.

4. Krogh, LF.C: Skyttesagen i Danmark, København 1911. p. 9-80/ Korsgaard, Ove: Kampen om Kroppen. Gyldendal 1982, p. 54-150.

5. Buytendijk, F.J.J: Wesen und Sinn des Spiels, Kurt Wolff Verlag, Berlin 1933. p. 10.

6. Fink, E.: The Ontology of Play. I: Gerber, E. W. (ed.): Sport and the Body, Lea \& Febiger, Philadelphia, 1972, p. 76-86.

7. C. Bøje \& H. Eichberg: Idrattens 3. vej. Klim, Randers (1994) p. 45-51.
8. Ibsen, B.: Frivilligt arbejde $i$ idratsforeninger. DHL/Systime. Viborg (1992) p. 122-132.

9. Møller, J.: Gamle Idratslege i Danmark. Vol. 1-4. DDSG\&I/Idrætsforsk. Kolding 1990/91.

10. Kulturpolitisk redegørelse afgivet af kulturminister Ebbe Lundgaard, nov. 1997.

11. Humanistisk Forskning. Det 21. århundrede: Videnskab - Virkelighed - Vision. Strategiplan 1998-2002. Statens Humanistiske Forskningsråd, København 1996, p. 34-35.

12. Evaluering af humaniora? Rapport fra arbejdsgruppen vedrørende evaluering af humanistisk forskning. Statens Humanistiske Forskningsråd, København 1997.

13. Københavns Universitet 1479-1979. Vol 2 Grane, L. \& K. Hørby: Almindelig historie 1788-1936. p. $1-611$.

14. Roland Renson: The Reinvention of Tradition in Sports and Games. I: Journal of Comparative Physical Education and Sport. Vol. xix, No. 2, 1997. Verlag Karl Hofmann p. 49. 